\title{
Camel Urine Promotes Sensitization to Doxorubicin by Inhibiting Epithelial-Mesenchymal Transition and Modulating NF-кB-Snail Signaling Pathway in Breast Cancer Cells
}

\author{
Mashael Saqer Al-Mutairi ${ }^{1 *}$, Ibtehal Kamal Matar ${ }^{1}$, Suad Alfadhli ${ }^{1}$, Awated \\ Al-Mutairi
}

\begin{abstract}
Background: Camel urine (CU) has been used as traditional treatment in the Arabian Peninsula for centuries. Although, researchers have reported CU anti-cancer effects, the exact mechanism(s) of action involved has not been fully elucidated. The epithelial-mesenchymal transition EMT is a phenotypic switch that promotes the acquisition of a fibroblastoid-like morphology by epithelial tumor cells, resulting in enhanced tumor cell motility and invasiveness. EMT has been shown to contribute to metastasis and chemoresistance of carcinomas. For that, in the present study, we have assessed the potential mechanism (s) by which CU exert its anti-cancer effects and its possible synergistic therapeutic effect with Doxorubicin (DOX) in breast cancer cells. Methods: Determination of anti-proliferative and apoptosis validation of CU was performed by 3-(4,5-Dimethylthiazol-2-yl)-2,5,-diphenyltetrazolium bromide (MTT), annexin-V-fluorescein isothiocyanate assays, and Western blot. EMT protein markers, migration and invasion of cells were determined by Western blot or immunofluorescent staining, Scratch assay, Transwell invasion assay, respectively. Results: CU applied a significant anti-cancer effect on breast cancer cells via induction of DNA damage and apoptosis in a concentration- and time-dependent manner. Also, CU remarkably reversed the EMT by downregulating N-cadherin and Vimentin expression and upregulating E-cadherin expression. As a result, the stemness, migration and invasion of breast cancer cells were also inhibited, which was likely mediated by NF-kB-Snail signalling pathway and its downstream inflammatory effectors. CU successfully enhanced DOX cytotoxicity by reversing EMT which possibly through inhibition of NF-kB-Snail signalling and subsequently inflammation. Thus, our study provides new mechanistic bases for the therapeutic application of CU that may improve the outcomes of anti-cancer chemotherapy.
\end{abstract}

Keywords: Chemoresistance- camel urine- breast cancer- NF-kB- EMT

Asian Pac J Cancer Prev, 22 (12), 4017-4029

\section{Introduction}

Breast cancer is the most common cancer affecting women worldwide (Siegel et al., 2020). Thousands of new cases are identified each year and an estimated 2.3 million new cases, representing $11.7 \%$ of all cancer cases and 685,000 deaths reported in 2020 (Sung et al., 2020). Although conventional treatment regimens such as chemotherapy can suppress the initial phases of breast cancer development, the high morbidly and mortality rate of the disease is dependent on its ability to metastasize (Chaffer and Weinberg, 2011; Bai et al., 2016). As the advanced cancer prognosis in breast cancer patients is correlated with the metastasis aggressive stage, a new effective adjuvant agents for the treat of metastatic breast cancer must be found.

The epithelial-mesenchymal transition (EMT), which has been identified to play an essential role in embryogenesis process and other fundamental activities such as wound healing and tissue remodeling (Kalluri and Weinberg, 2009b; Yan et al., 2010), is found to be involved in cancer progression, poor disease prognosis, and resistance to chemotherapy (Turner and Reis-Filho, 2013; Hu et al., 2016; Kubiliūtè et al., 2016; Sadreddini et al., 2017). EMT, followed by polarity loss and motility gain, has been shown to play a crucial role in the metastasis process (Brabletz, 2012; Hou et al., 2014). Epithelial protein markers such as E-cadherin that typically encourage cell-cell contact may be lost during EMT, while cells acquire mesenchymal protein markers such as $\mathrm{N}$-cadherin and Vimentin to boost their ability to migrate and invade. Both steps are crucial events in the initial phase of metastasis (Polyak and Weinberg, 2009; Thiery et al., 2009). In addition, metalloproteinases (MMPs), which are secreted by tumor cells undergoing EMT, degrade the structural components of the extracellular matrix to 
promote tumor cell migration while activating growth factors or inactivating protease inhibitors at the same time (Groblewska et al., 2010). Studies have also shown that EMT is involved in cancer stem cells (CSCs) generation (Brabletz, 2012; Mani et al., 2008; Singh and Settleman, 2010). CSCs are a small subpopulation of cancer cells that self-renew and contribute to cancer metastasis and chemoresistance (Abdullah and Chow, 2013; VelascoVelázquez et al., 2011).

Numerous reports have shown that initiation of EMT and post-EMT maintenance depend on the microenvironment and the production of inflammatory cytokines (Jing et al., 2011; Scheel et al., 2011). Cancerrelated inflammation is now recognized as a hallmark of cancer, and inflammation-related pathways have been targeted as a possible therapy option for cancer patients (Mantovani, 2018). One of the most commonly characterized pathway used by cancer cells to induce inflammation is NF- $\kappa \mathrm{B}$ signaling (Grivennikov et al., 2010). NF- $\kappa B$ is crucial for carcinogenesis of many cancers as its activation stimulates tumor development and progression (Gupta et al., 2010). In the context of EMT, it has been documented that NF- $\kappa \mathrm{B}$ directly activates Snail which is a well-established transcriptional regulator of EMT (Chua et al., 2007). Thus, inhibition

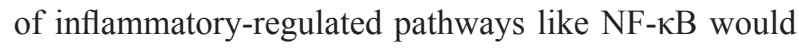
suppress EMT and could potentially lead to more effective therapeutic options.

CU has been used as a traditional treatment for several diseases such as skin diseases in the Arabian Peninsula for centuries. Studies have documented the pharmacological effects of CU to include; anti-fungal and anti-inflammatory properties (Al-Bashan, 2011; Al-Yousef et al., 2012). Moreover, the chemical constituents of CU also contain metabolites like canavanine, a byproduct of the metabolism of amino acids and urea, that demonstrated a potent activity against tumor cells (Ahamad et al., 2017). This is in accordance with previous reports that have shown CU to have anti-cancer effects on different types of tumors (Al-Yousef et al., 2012; Alghamdi Z, 2012). Also, to induce cell death through DNA fragmentation, regulate inflammation-related genes and disrupt metastasis by down regulating several angiogenesis-related proteins in breast cancer cells (Romli et al., 2017).

As the necessity to identify substances that modulate the survival or malignancy of cancer cells in rise and considering the essential function of EMT in tumor metastasis and therapeutic resistance, the present study aimed to explore the possible mechanism(s) by which CU exert its anti-cancer effects precisely on the metastasis potential of cancer cells and chemotherapy efficacy.

\section{Materials and Methods}

\section{Materials}

All chemicals used were of analytical grade and were obtained from Sigma. The following antibodies were purchased from Cell signaling technology: Caspase-3, cleaved Caspase-3, Caspase 9, PARP, Cleaved PARP, E-cadherin, Vimentin, p- $\gamma$-H2Ax, Snail, STAT3, p-STAT3 and rabbit secondary antibody. Antibodies against NF- $\kappa \mathrm{B} /$ p65, Bax, Bxl-xl, $\beta$-Actin, IкB- $\alpha$ and mouse secondary antibodies were purchased from Santa Cruz Biotechnology. Antibody against COX-2 was obtained from Cayman chemical, ALDH1 from Abcam and N-cadherin from BD Bioscience. RIPA lysis buffer was purchased from SigmaAldrich. Enhanced chemiluminescence detection kit was from Bio-Rad. Doxorubicin and 3-(4,5-dimethylthiazol-2yl)-2,5-diphenyl tetrazolium bromide was obtained from Sigma-Aldrich.

\section{Preparation of camel urine sample}

The urine samples were collected from female virgin (1-5 years) from Kuwait desert and placed in sterile containers. Samples were then transferred to glass vials and lyophilized using Savant freeze dryer (Thermo Scientific, Savant Speed Vac SC210A, Germany) instrument in which the urine was converted into powder as a result of evaporation. The lyophilized urine was collected in an amber glass bottle and refrigerated at $4{ }^{\circ} \mathrm{C}$. Stock solution was prepared by dissolving the powdered urine sample in sterile distilled water and filtered through Minisart syringe filter (Sigma, St Louis, MO) pore size 0.2 $\mu \mathrm{M}$, aliquot and kept at $-20^{\circ} \mathrm{C}$ until further use.

\section{Cell culture}

MDA-MB-231 and MCF-7 cells (generous gift from Dr Abdelilah Aboussekhra, King Faisal Specialist Hospital and Research Center, KSA). Cells were grown in RPMI 164 supplemented with $2 \mathrm{mM}$ L-glutamine, and $25 \mathrm{mM}$ HEPES, $10 \%$ heat inactivated foetal Calf serum, Penicillin (100 unit $/ \mathrm{ml})$, and Streptomycin $(100 \mu \mathrm{g} / \mathrm{ml})$, at $37^{\circ} \mathrm{C}$ in humidified atmosphere of $5 \% \mathrm{CO}_{2}$. Cells in passages $1-4$ were used. Cells were treated with various concentrations of CU $(5-30 \mathrm{mg} / \mathrm{mL})$ and DOX $(1 \mu \mathrm{M})$ for different time periods.

\section{Mitochondrial extract}

After incubation with $\mathrm{CU}(5-30 \mathrm{mg} / \mathrm{ml})$ or DOX $(1 \mu \mathrm{M})$ or both, breast cancer cells $(2 \times 107$ cells $)$ were pelleted by centrifuging at $\sim 850 \times \mathrm{g}$ for $2 \mathrm{~min}$. The extraction was performed according to the manufacturer's instructions from the mitochondrial isolation kit (Thermo scientific). The supernatant was discarded and $800 \mu \mathrm{l}$ of mitochondria isolation reagent $\mathrm{A}$ was added to the pellet, then vortexed at medium speed for $5 \mathrm{sec}$ and incubated on ice for exactly $2 \mathrm{~min}$. Subsequently, $10 \mu \mathrm{l}$ of mitochondria isolation reagent $\mathrm{B}$ was added, vortexed at maximum speed for $5 \mathrm{sec}$, and incubated on ice for $5 \mathrm{~min}$. $800 \mu \mathrm{l}$ of mitochondria isolation reagent $\mathrm{C}$ was then added and tubes were inverted several times to mix, centrifuged at $700 \times \mathrm{g}$ for $10 \mathrm{~min}$ at $4^{\circ} \mathrm{C}$ and supernatant was transferred to a new tube and centrifuged at 3,000 $\times \mathrm{g}$ for $15 \mathrm{~min}$. The supernatant (cytosol fraction) was transferred to a new tube and kept at $-20^{\circ} \mathrm{C}, 500 \mu \mathrm{l}$ of mitochondria isolation reagent $\mathrm{C}$ was then added to the pellet which was centrifuged at $12,000 \times \mathrm{g}$ for $5 \mathrm{~min}$. The supernatant was discarded and $50 \mu 1$ of RIPA lysis buffer was added to the pellet and vortexed for 30 min Finally, the tube was spun for $5 \mathrm{~min}$ at $12,000 \mathrm{xg}$, supernatant was collected, and protein concentration was determined using Epoch microplate spectrophotometer. 


\section{Western blot analysis}

After treatment, adherent cells were gently scraped from the plates into the medium containing floating cells to obtain all the cells. Cells were then centrifuged, washed in PBS, lysed in ice-cold RIPA lysis buffer containing protease inhibitor cocktail (Roche, Mannheim, Germany) to obtain total protein. Protein concentrations were determined using Epoch microplate spectrophotometer. Then proteins $(10-60 \mathrm{ug} / \mathrm{ml})$ were denatured by boiling with $1 \mathrm{x}$ SDS sample buffer with DTT for $5 \mathrm{~min}$, separated by $10-15 \%$ SDS-PAGE and transferred to a nitrocellulose membrane. The membranes were blocked for non-specific binding for $1 \mathrm{hr}$ in $2 \% \mathrm{BSA}(\mathrm{w} / \mathrm{v})$ diluted in TBST buffer $(50 \mathrm{mM}$ Tris- $\mathrm{HCl}, 150 \mathrm{mM} \mathrm{NaCl}, 0.2 \%$ (v/v) Tween-20) and incubated overnight with primary antibody diluted in $0.2 \% \mathrm{BSA}(\mathrm{w} / \mathrm{v})$ in TBST buffer at $4{ }^{\circ} \mathrm{C}$. The blots were washed with TBST buffer for 5 $\min (3 \mathrm{x})$ and incubated with HRP-conjugated secondary antibody in $0.2 \% \mathrm{BSA}(\mathrm{w} / \mathrm{v})$ diluted in TBST buffer for $2 \mathrm{hr}$. Detection was done by chemiluminescence, using enhanced chemiluminescence detection kit and then exposed to KODAK film. Densitometric analyses were done using the Quantity one software of the GS-800 calibrated densitometer (Bio-Rad). The used nitrocellulose membranes were stripped and reused for detection of housekeeping protein $\beta$-Actin.

\section{Immunofluorescent staining}

MDA-MB 231 cells were grown in confocal dishes and were treated with CU for $24 \mathrm{hrs}$, fixed with $70 \%$ ice cold methanol, then kept stable in $0.2 \%$ Triton for 10 min to rupture the cell membranes. Following $3 x$ PBS washing, non-specific antigen-binding sites were blocked by $2 \%$ BSA for $30 \mathrm{~min}$. The cells were then incubated with either anti-N-cadherin, Vimentin, or anti-E-cadherin antibody (1:200) for $1 \mathrm{hr}$ followed by washing with $3 \mathrm{x}$ PBS, incubated for $1 \mathrm{hr}$ with a mixture of fluorescencetagged secondary anti $\neg$ body with DAPI. After washing, dishes were kept from light at $4{ }^{\circ} \mathrm{C}$ overnight and images were captured at 40x magnification using Ziess Meta 510 confocal microscopy.

\section{MTT cytotoxic assay}

Cells were seeded into 96-well plates at $2.5 \times 10^{4}$ per well and allowed to adhere overnight. CU (0-30 $\mathrm{mg} / \mathrm{ml}$ ) or $\mathrm{dH} 2 \mathrm{O}$ alone were added for 24,48 and 72 hrs. After incubation terminated, the medium was replaced with $0.5 \mathrm{mg} / \mathrm{ml}$ MTT [3-(4,5-dimethylthiazol2-yl)-2,5-diphenyl tetrazolium bromide] and incubated for I hr. Next, supernatants were removed, and the resulting MTT formazan was solubilized in $100 \mu \mathrm{l}$ of DMSO and absorbance was recorded using a multiscan spectrophotometer (Thermo scientific, CA, USA) at 570 $\mathrm{nm}$ with a reference at $650 \mathrm{~nm}$. The effect of CU on cell survival was assessed as the percentage of cell viability compared with the control cells, which were arbitrarily assigned 100\% Survival.

\section{Cell viability assay}

Cells were seeded into 12-wells plates at 3x 105 per well and allowed to adhere overnight. Cells were then treated with CU $(0-30 \mathrm{mg} / \mathrm{ml})$ or DOX $(1 \mu \mathrm{M})$ or both and incubated for $24 \mathrm{hrs}$ before trypsinization and counting using Vi-Cell analyzer (Beckman Coulter, USA). Data was presented as proportional viability (\%) by comparing the treated group with the untreated cells, the viability of which is assumed to be $100 \%$. Cell morphological changes were detected by either Ziess axiovert-40 phase contrast microscopy or cell observer.

\section{Flow cytometer analysis}

After 24 hrs incubation with CU, medium containing floating cells from petri dishes were collected and deposited in their corresponding tube and then $700 \mu l$ of trypsin was added to each plate and incubated for $3 \mathrm{~min}$. Media was added to deactivate the trypsin and the cells were collected in their corresponding tubes, centrifuged at 1,500 rpm for $5 \mathrm{~min}$. The supernatant was then discarded, and the pellet was washed $2 \mathrm{x}$ with PBS. Pellets were resuspended with $100 \mu \mathrm{l}$ of binding buffer then $10 \mu \mathrm{l}$ of Annexin V (fluorescein isothiocynate FITC) and $100 \mu \mathrm{l}$ 7AAD were added. The volume was completed to 500 $\mu \mathrm{l}$ with binding buffer. Flow cytometry (CYTOMIC FC 500, Beckman, Germany) was performed after $15 \mathrm{~min}$ incubation in dark. Data acquisition was performed using FACSDiva 6.1 software.

\section{Scratch assay}

Wound healing assay was performed to assess the motility of cells exposed to CU. MDA-MB-231 cells were seeded in 6-well plates and cultured for $24 \mathrm{hrs}$ to grew up to $90-100 \%$ confluence. After scraping the cell monolayer with a sterile micropipette tip, the wells were washed with PBS, and treated with CU $(5-10 \mathrm{mg} / \mathrm{ml})$ or DOX $(1 \mu \mathrm{M})$ or both for 8 and $24 \mathrm{hrs}$. The first image of each scratch was obtained at time zero. At 8 or $24 \mathrm{hrs}$, each scratch was examined and captured under an inverted microscopy (Ziess axiovert-40 phase contrast microscopy) at the same location and the healed area was measured. The rate of migration was determined using the following formula: (Area of wound at $0 \mathrm{hr}$ - Area of wound at (n) hr/ Area of wound at $0 \mathrm{hr}) \mathrm{X} 100$.

\section{Transwell invasion assay}

The invasion of MDA-MB-231 cells was assessed in transwell chambers equipped with $8 \mu \mathrm{m}$ pore size, $6.5 \mathrm{~mm}$ diameter polycarbonated membranes (Corning Costar Inc., Corning, NY, USA). The extracellular matrix Matrigel (Corning Costar Inc., Corning, NY, USA) at $50 \mu \mathrm{l} / \mathrm{cm}^{2}$ was added to the surface of the polycarbonate membrane in the transwell chamber, and then placed under a fume hood either at $37^{\circ} \mathrm{C}$ or at room temperature for $30 \mathrm{~min}$ until the Matrigel gelled. The cells were seeded onto the upper wells at a concentration of $1 \times 10^{5}$ cells/well in $100 \mu \mathrm{l} \mathrm{serum}$-free medium and then cultured for $48 \mathrm{hrs}$ following treatment with $\mathrm{CU}(10 \mathrm{mg} / \mathrm{ml})$ or co-treatment with DOX $(1 \mu \mathrm{M})$. The bottom chambers of the transwell were filled with $600 \mu \mathrm{l}$ medium containing $10 \%$ FBS. After incubation for $48 \mathrm{hrs}$, the non-migratory cells on the upper surface of the chambers were removed by a cotton swab and the migrated cells were fixed with $100 \%$ methanol for $10 \mathrm{~min}$ at room temperature and stained with $0.1 \%$ crystal 
violet. Five randomly chosen fields were photographed under a light microscope (Ziess axiovert-40 phase contrast microscopy) at a magnification of 20x.

\section{Cytokine ELISA assay}

After treating cells with CU or DOX or both for $24 \mathrm{hrs,}$ supernatants were collected and clarified by centrifugation at $3000 \times$ g. Commercially available ELISA assay (The quantikine human IL-6 immunoassay and Human IL-8/ CXCL8 kits, R\&D Systems) was used to measure levels of IL-6 and IL-8. The assays were conducted according to the manufacturer's instructions. calibration curves were prepared using purified standards provided with the ELISA kit.

\section{Statistical analysis}

Statistical analysis was performed with Prism graph-pad (v.6). All data are presented as means \pm S.D. Differences between experimental conditions were determined by two-tailed Student's t test. ${ }^{*} \mathrm{P}<0.05$, ** $\mathrm{P}<0.01$ and $* * * \mathrm{P}<0.001$ indicate statistical relevance. All experiments were repeated independently at least three times

A
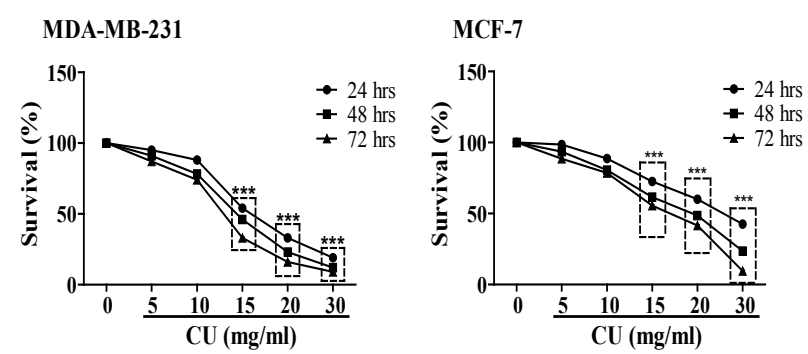

C
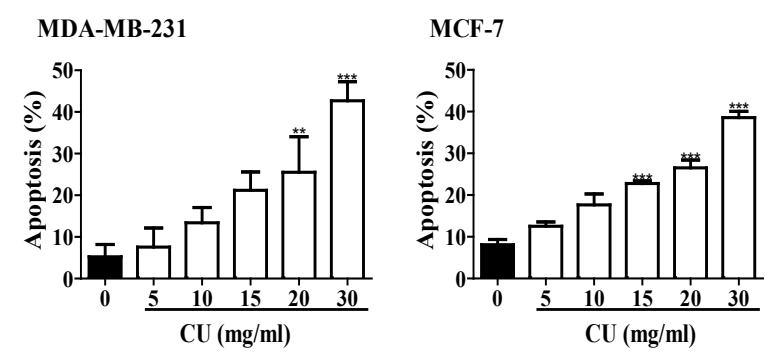

\section{Results}

CU reduces viability and induces apoptosis in breast cancer cells

As shown in Figure 1A, MDA-MB-231 cells were treated with increasing concentrations of CU $(5-30 \mathrm{mg} / \mathrm{ml})$ for 24,48 or $72 \mathrm{hrs}$. CU significantly inhibited proliferation in a concentration- and time-dependent manner when compared to control group. Similarly, CU significantly inhibited MCF-7 cells (poorly invasive ER+) proliferation in a concentration-and time-dependent manner (Figure 1A). Both cell lines viability was measured, and results revealed a gradual concentration-dependent reduction in cells growth at $24 \mathrm{hrs}$ post-treatment. The maximum inhibition was observed in cells treated with 20 and 30 $\mathrm{mg} / \mathrm{ml}$ (Figure 1B). Based on these results, CU potently inhibit breast cancer cells growth.

Apoptosis was observed using Annexin V staining in MDA-MB-231 cells that had been exposed to increasing concentrations of CU (5 to $30 \mathrm{mg} / \mathrm{ml}$ ) for $24 \mathrm{hrs}$. As shown in Figure 1C, a gradual increase in the number of apoptotic cells was detected as the CU concentration increased. A significant percentage of cells had undergone apoptosis at concentrations of 20 and $30 \mathrm{mg} / \mathrm{ml}(\mathrm{P}<0.001$ and $\mathrm{P}<0.001$, respectively) compared with untreated cells. Likewise, $\mathrm{CU}$ induced apoptosis in MCF-7 cells in a

B

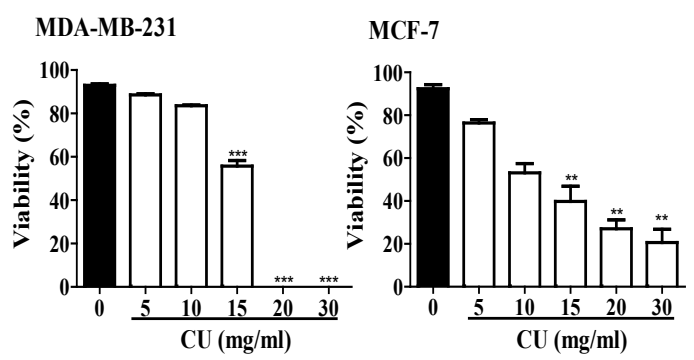

D

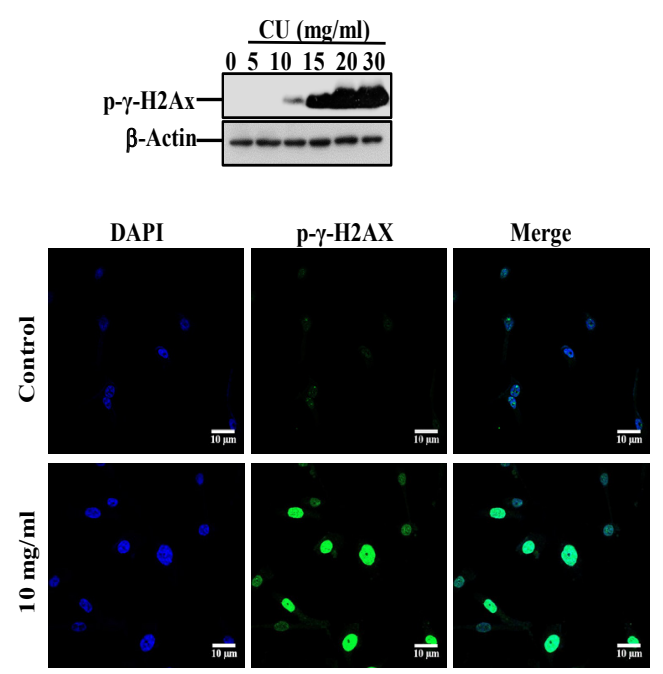

Figure 1. The Effect of CU on MDA-MB-231 and MCF-7 Breast Cancer Cells Growth. Cells were treated with indicated CU concentrations $(5-30 \mathrm{mg} / \mathrm{ml})$ for 24,48 , and $72 \mathrm{hrs}$ then assessed for (A) \% of cell survival using MTT assay (B) cell viability and (C) apoptosis by labelling cells with Annexin V-tagged FITC/7AAD then analyzed using flow-cytometry. (D) cell lysates were prepared, separated by SDS PAGE, and then assessed for $\mathrm{p}-\gamma-\mathrm{H} 2 \mathrm{AX}$ and $\beta$-Actin. Fluorescent images were acquired by confocal scanning microscopy. Each value represents mean \pm S.E.M of three independent experiments. $*: \mathrm{p}<0.05, * *: \mathrm{p}<0.01, * * *: \mathrm{p}<0.001$ treated vs. the control experimental groups. 

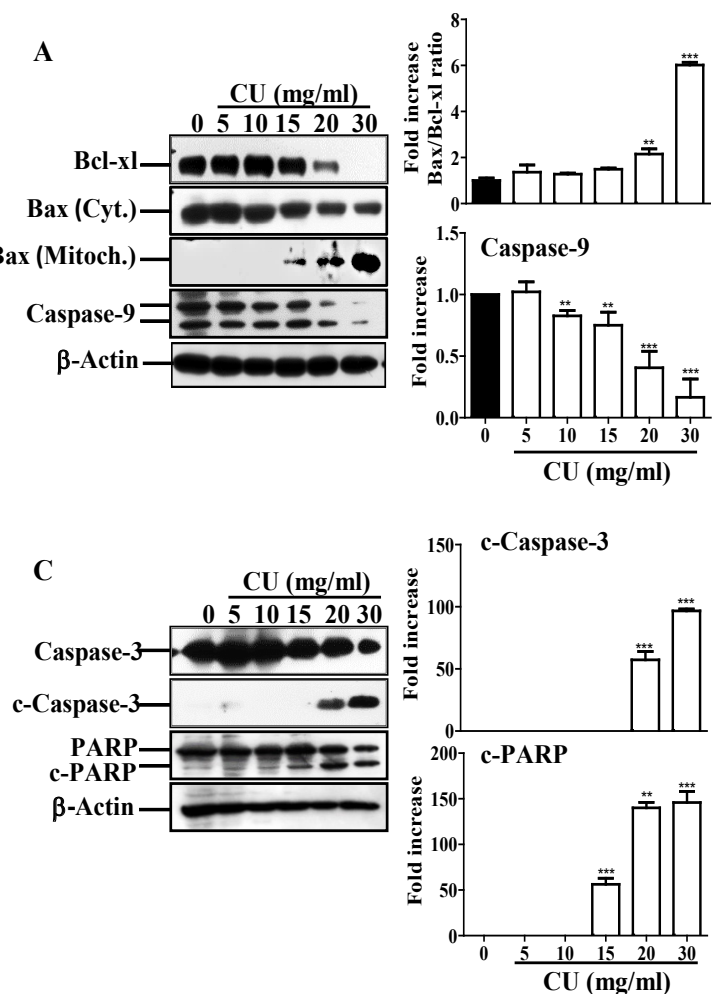
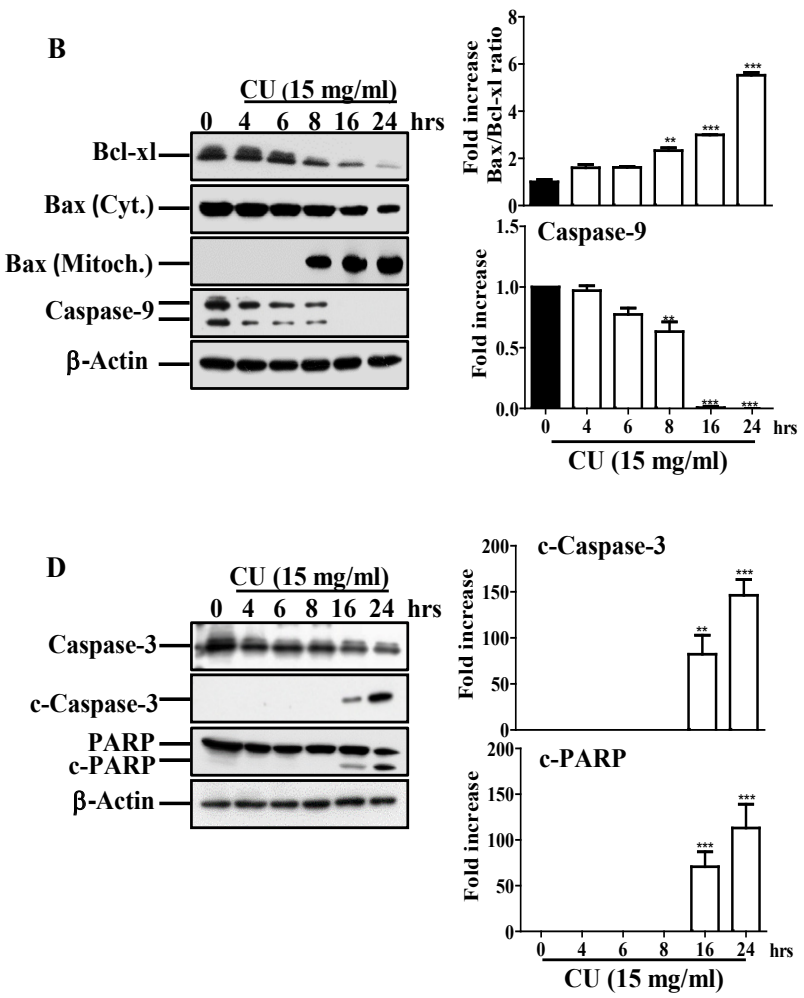

Figure 2. CU Induces Apoptosis Via the Intrinsic Mitochondrial Cascade in MDA-MB-231 Cells. Cells were treated with indicated concentrations of CU $(5-30 \mathrm{mg} / \mathrm{ml})$ for $24 \mathrm{hrs}$ or with $15 \mathrm{mg} / \mathrm{ml}$ for various time intervals, then cell lysates were prepared, separated by SDS PAGE, and assessed for (A), (B) Bcl-xl, Bax cytosolic and mitochondrial, $\beta$-Actin, and Caspase-9. (C). (D) Assessed for apoptotic proteins Caspase-3, c-Caspase-3, PARP, c-PARP and $\beta$-Actin. Each value represents mean \pm S.E.M of three independent experiments. Each value represents mean \pm S.E.M of three independent experiments. Significant differences ${ }^{*} \mathrm{p}<0.05,{ }^{* *} \mathrm{p}<0.01,{ }^{* * *} \mathrm{p}<0.001$ between control and experimental groups.

concentration-dependent manner (Figure 1C). Consistent with this finding, the levels of the phosphorylated $\gamma-\mathrm{H} 2 \mathrm{AX}$ protein in MDA-MB-231 cells were increased upon treatment with $\mathrm{CU}$ in a concentration-dependent manner, indicative of the accumulation of DNA double strand breaks (Figure ID). Immunostaining also showed a clear increase in $\mathrm{p}-\gamma-\mathrm{H} 2 \mathrm{AX}$ expression in the nucleus after treatment with $\mathrm{CU}$ at a concentration as low as $10 \mathrm{mg}$ / $\mathrm{ml}$ for $24 \mathrm{hrs}$ compared to untreated cells. These results indicate that $\mathrm{CU}$ decreases the viability of breast cancer cells by stimulating apoptosis process. As CU produced similar effect on both cell types, MDA-MB-231 cells were chosen for subsequent experiments.

\section{CU triggers apoptosis via the intrinsic mitochondrial cascade}

The balance between pro-apoptotic and pro-survival Bcl-2 family proteins was assessed to ascertain the involvement of the mitochondrial apoptosis pathway in CU-mediated apoptosis, as this balance is involved in the initiation of mitochondrial apoptotic cascade (Delivani and Martin, 2006). As shown in Figure 2A, a 24 hrs CU treatment significantly downregulated the cytosolic levels of the pro-survival protein Bcl-xl in a concentrationdependent manner, which was completely abolished at 30 $\mathrm{mg} / \mathrm{ml}$ of CU. Similarly, the cytosolic levels of the proapoptotic protein Bax gradually decreased, along with an increase in Bax protein expression in the mitochondria that peaked at $30 \mathrm{mg} / \mathrm{ml}$. The decrease in the cytosolic levels of Bcl-xl and Bax proteins occurred in a time-dependent manner when cells were treated for 24 hrs with CU (15 $\mathrm{mg} / \mathrm{ml}$, IC50) (Figure 2B). CU treatment increases the Bax: Bcl-xl ratio, leading to initiation of the mitochondrial apoptosis pathway in MDA-MB-231 cells.

Next, Caspase-9 involvement was analysed by immunoblotting, and as shown in Figure 2A, a concentration-dependent decrease in the expression of pro-Caspase- 9 was observed upon a $24 \mathrm{hrs}$ treatment with CU. In agreement with this result, Figure 2B shows a time-dependent decrease in the expression of proCaspase-9 that reached its minimum values at $16 \mathrm{hrs}$, which was maintained up to $24 \mathrm{hrs}$. This result was in consistent with the concentration-dependent decrease in the expression of downstream pro-Caspase-3 (Figure 2C), which was associated with an increase in active Caspase-3 (c-Caspase-3) and cleaved PARP, c-PARP. Furthermore, a time-dependent decrease in the expression of proCaspase- 3 was associated with an increase in c-Caspase-3 expression and subsequently, c-PARP (Figure 2D). Thus, $\mathrm{CU}$ activated the intrinsic Caspase pathway in both a concentration- and time-dependent manner.

$C U$ reverts $M D A-M B-231$ breast cancer cells towards an epithelial phenotype and inhibits CSC-associated markers

We then investigated whether CU exerted any effect on the EMT process in breast cancer cells. As shown in 
A

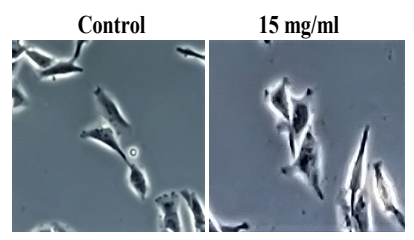

$\mathrm{C}$

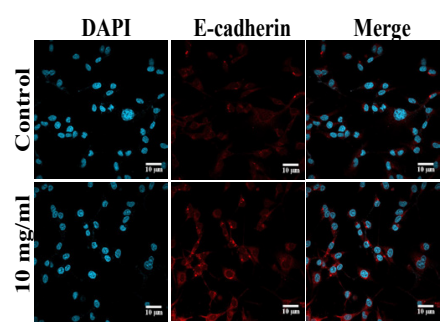

E
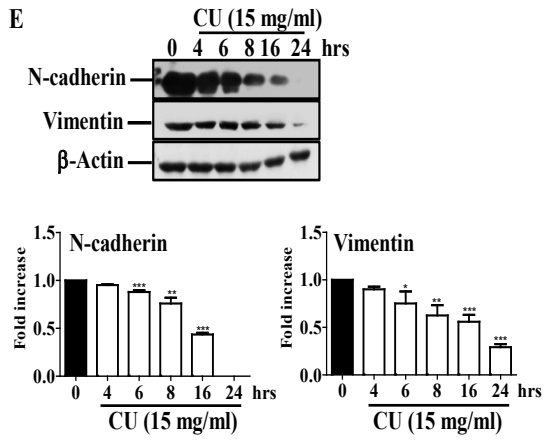

B
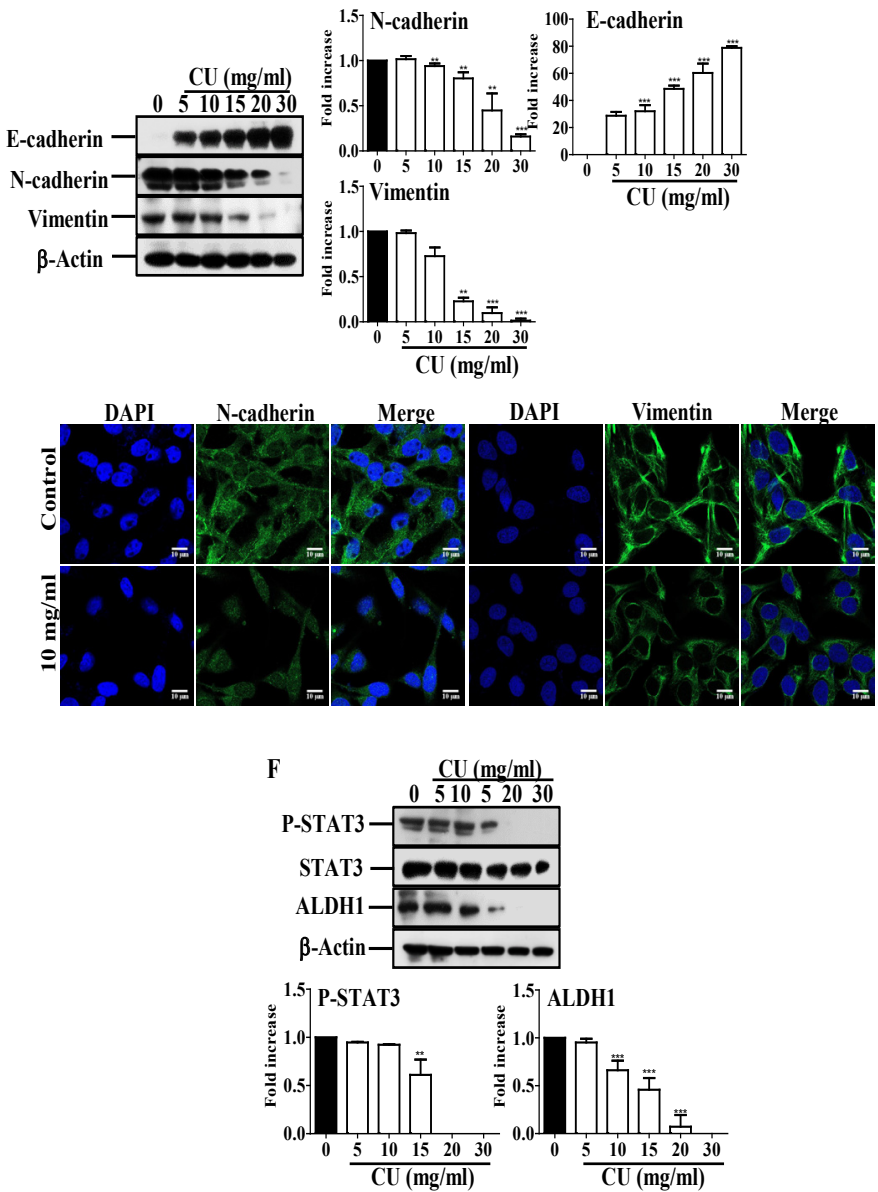

Figure 3. CU Reverses EMT and Inhibits Stemness in MDA-MB-231 Breast Cancer Cells. Cells were treated with CU $(5-30 \mathrm{mg} / \mathrm{ml}$ or $15 \mathrm{mg} / \mathrm{ml})$ for the indicated time then (A) The morphological changes in MDA-MB-231 cells were detected using cell observe (20x). Cell lysates were prepared, separated by SDS PAGE, and assessed for (B), (D) E-cadherin, N-cadherin, Vimentin, (E) p-STAT3, STAT3, ALDH1 and b-Actin. (C) Confocal immunofluorescent images for E-cadherin, N-cadherin and Vimentin localization. Each value represents mean \pm S.E.M of three independent experiments. Significant differences $* \mathrm{p}<0.05, * * \mathrm{p}<0.01, * * * \mathrm{p}<0.001$ between control and experimental groups.

Figure $3 \mathrm{~A}$, cells treated with $15 \mathrm{mg} / \mathrm{ml}$ of CU presented an obvious morphological change from the spindle phenotype (mesenchymal phenotype) to a rounded or cobblestone phenotype (epithelial phenotype). Accompanying the morphological changes, levels of protein markers of EMT were also changed. The protein expression levels of epithelial marker E-cadherin were significantly increased in a concentration-dependent manner after 24 hrs from CU treatment (Figure 3B). In contrast, the protein expression levels of mesenchymal markers $\mathrm{N}$-cadherin and Vimentin were markedly decreased in a concentrationdependent manner (Figure 3B). Consistent with these results, the immunofluorescence assays confirmed that CU significantly increased E-cadherin expression in the cytosol (Figure 3C) and decreased the cellular expression of N-cadherin and Vimentin (Figure 3D). In addition, a time-dependent decrease in the expression of both $\mathrm{N}$-cadherin and Vimentin proteins was observed (Figure $3 \mathrm{E})$. The data suggests that $\mathrm{CU}$ may promotes the mesenchymal-epithelial transition (MET) process.

EMT and CSC formation are closely associated processes; since, evidence have shown that EMT could induce CSC characteristics (Mani et al., 2008), we decided to investigate the importance of CU-mediating EMT inhibition on the CSC phenotype. STAT3 is known to play an important role in proliferation and self-renewal of CSCs in various cancer types including breast cancer (Marotta et al., 2011); its activation upregulates the secretion of various cytokines including IL-6 and IL-8 and promotes the development of CSCs (Elinav et al., 2013). CU significantly abrogated the constitutive activation of STAT3 in a concentration-dependent manner (Figure 3F). As a result, STAT3-mediated stem cell marker ALDH1 protein expression was effectively suppressed in a concentration-dependent manner (Figure $3 \mathrm{~F}$ ). Together, these results suggest a possible molecular mechanism underlying the inhibitory effects of $\mathrm{CU}$ on CSC development with potential implications for CSC enrichment induced by chemotherapeutic drugs.

CU inhibits the inflammatory response elicited by breast cancer cells and impairs their migration and invasion ability.

The NF- $\kappa$ B pathway was reported to play an important role in orchestrating the inflammatory process (Yao et al., 2007); therefore, we evaluated the effect of CU on the expression of $\mathrm{NF}-\mathrm{\kappa B} / \mathrm{p} 65$ protein, which represent its active form. In addition to protecting the upstream inhibitor of NF- $\kappa \mathrm{B} / \mathrm{p} 65$, I $\kappa \mathrm{B}-\square \square$ from degradation, 
A
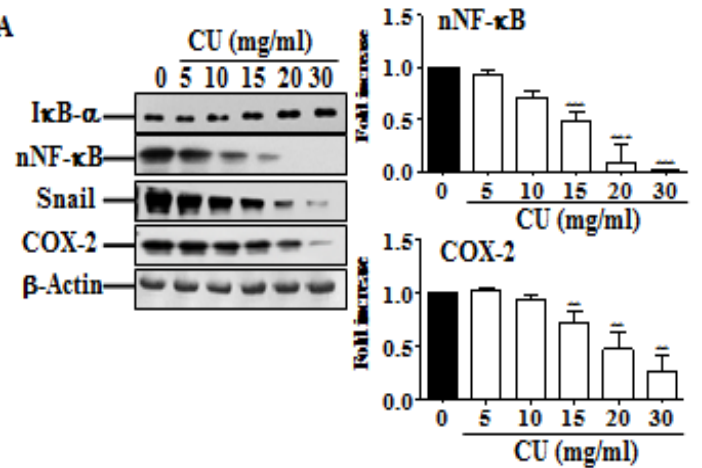

B

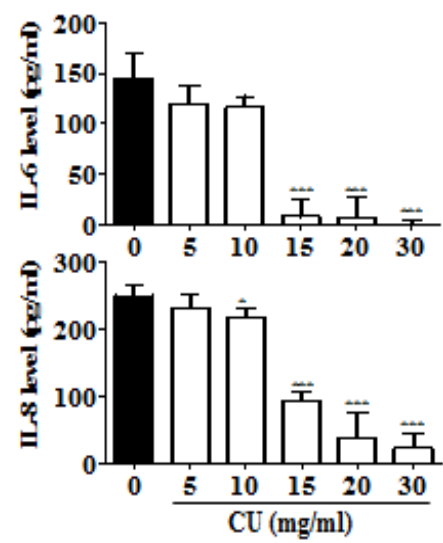

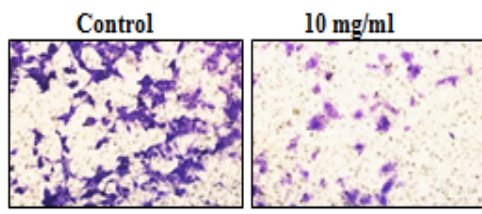
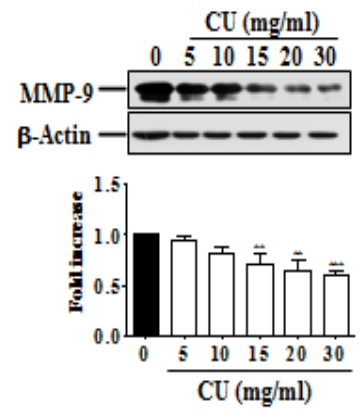

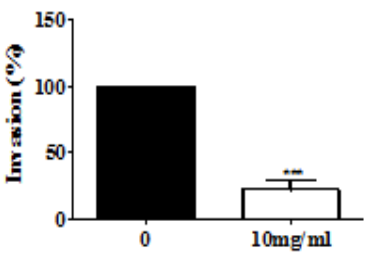

D

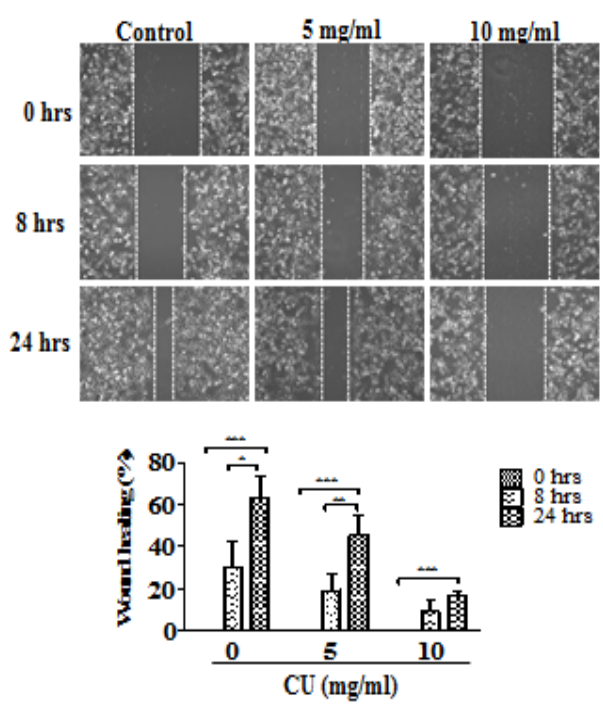

Figure 4. CU Inhibits Inflammation, Migration and Invasion in MDA-MB-231 Cells. Cells were treated with indicated CU concentrations for $24 \mathrm{hrs}$ then (A), (C) cell lysates were prepared, separated by SDS PAGE, and assessed for IkB-a, NF-kB/p65, Snail, COX-2, MMP-9 and b-Actin. (B) Media was collected after incubation and analyzed for cytokines IL-8 and IL-6 protein levels by ELISA assay kit. (C) Invasion assays were performed, photographed (40x) and counted in 6 random fields for each treatment. (D) Wounded regions were photographed (10x) and \% of wound closure was evaluated and the result expressed as a percentage based on the ratio of the treated cells to the controls. Each value represents mean \pm S.E.M of three independent experiments. Significant differences $* p<0.05, * * p<0.01$ and $* * * \mathrm{p}<0.001$ between control and experimental groups.

$\mathrm{NF}-\kappa \mathrm{B} / \mathrm{p} 65$ nuclear $(\mathrm{n}-\mathrm{NF}-\kappa \mathrm{B})$ translocation was downregulated by $\mathrm{CU}$ in a concentration-dependent manner (Figure 4A). NF- $\mathrm{BB}$ has been reported to induce Snail promoter activity (Cichon and Radisky, 2014, Song et al., 2014), thus, Snail protein expression was important to be assessed. As shown in Figure 4A, Snail protein expression was consistent with the downregulation of $\mathrm{NF}-\kappa \mathrm{B} / \mathrm{p} 65$ protein. Indeed, control cells expressed high levels of this signalling molecule, whereas its levels were remarkably diminished in CU-treated cells. These results confirmed that NF- $\kappa \mathrm{B} / \mathrm{p} 65$ promotes Snail expression in MDA-MB-231 cells and potentially inhibits their activation. To confirm this result, we investigated the expression of one of the molecular components of NF$\kappa \mathrm{B}$ signalling pathway, COX-2, an inducible enzyme which overexpressed in breast cancer (Sobolewski et al., 2010). As expected, control cells expressed high levels of COX-2, whereas a concentration-dependent decrease in COX-2 expression was observed in CU-treated cells (Figure 4A). Other pro-inflammatory mediators that are controlled by NF- $\mathrm{BB} /$ Snail signalling pathway are IL-6 and IL-8 cytokines. Levels of both cytokines were significantly reduced when cells were treated with CU in a concentration-dependent manner compared to control cells (Figure 4B).

Malignant cells undergoing EMT display an increase in the motility and take advantage of the acquisition of the mesenchymal phenotype to become highly invasive. In the presence of $\mathrm{CU}$, a significant decrease $(\mathrm{P}<0.001)$ in invasiveness was observed (Figure $4 \mathrm{C})$. This behaviour was significantly associated with a decrease in metalloproteinase-9 (MMP-9) levels after CU treatment (Figure 4C). MMPs are required to degrade the extracellular matrix (ECM), and reduced metalloproteinase activity is likely to hinder the invasion of cancer cells. Similarly, wound-healing assay result showed that the motility of 
A

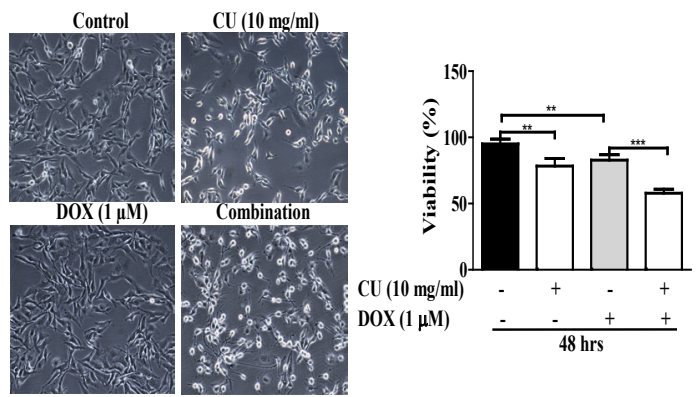

C

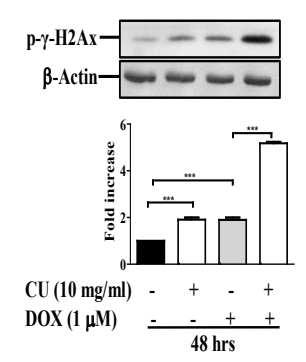

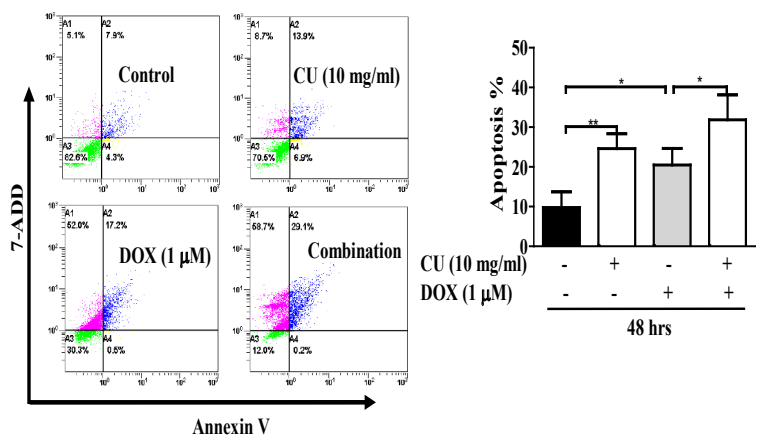

E

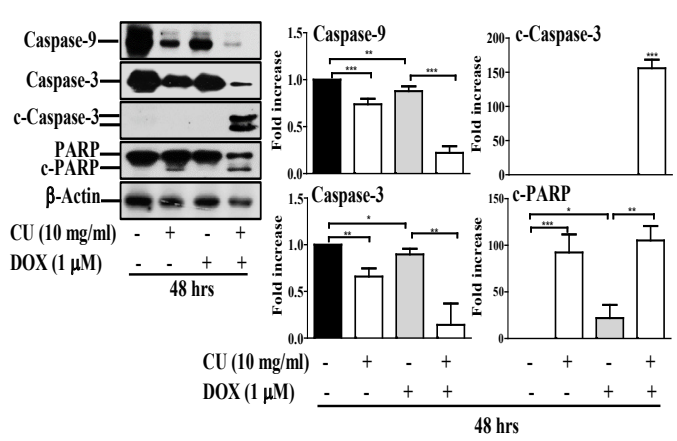

Figure 5. CU Enhances Doxorubicin-Induced Apoptosis in MDA-MB-231 Breast Cancer Cells. Cells were treated with CU $(10 \mathrm{mg} / \mathrm{ml})$ or DOX $(1 \mathrm{mM})$ alone or both for $48 \mathrm{hrs}$, then (A) \% of viable cells was detected by phase contrast microscopy (20x) and quantified. (B) Apoptosis was detected by labelling cells with Annexin V-tagged FITC/7AAD and analyzed by flow-cytometry. Cell lysates were prepared, separated by SDS PAGE, and then assessed for (C) p- $\gamma$-H2AX and b-Actin, (D) Bcl-xl and BAX cytosolic and mitochondrial fractions. (E) Caspase-9, Caspase-3, c-Caspase-3, PARP and c-PARP. Each value represents mean \pm S.E.M of three independent experiments. Significant differences $* \mathrm{p}<0.05, * * \mathrm{p}<0.01, * * * \mathrm{p}<0.001$ between control, DOX and combined treatment groups.

A

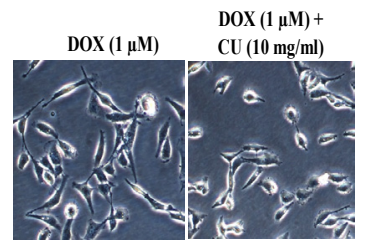

C

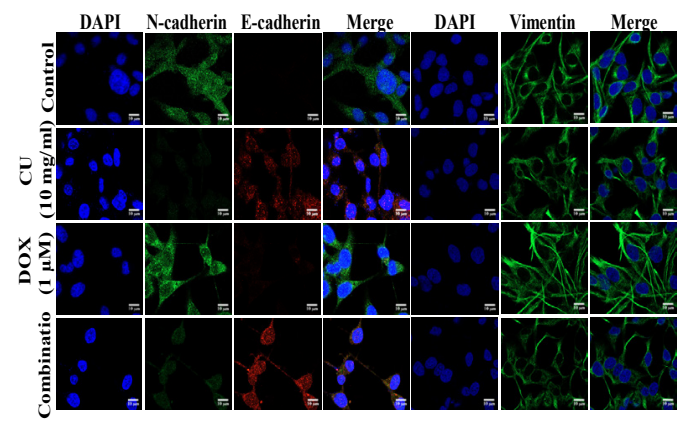

B

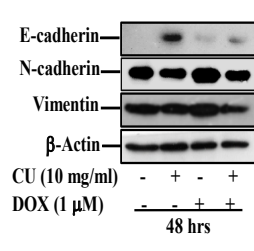

$\mathrm{CU}(10 \mathrm{mg} / \mathrm{ml})$ $\operatorname{DOX}(1 \mu \mathrm{M})$

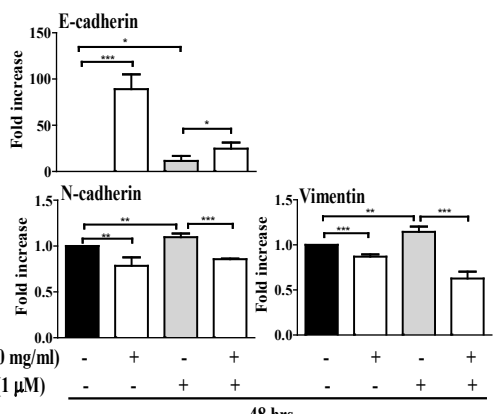

48 hrs

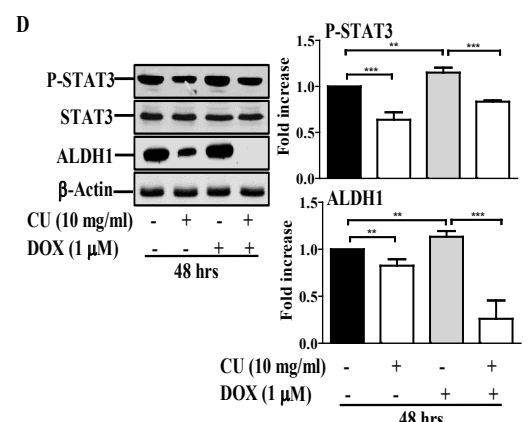

Figure 6. CU Reverses Doxorubicin-Induce EMT in MDA-MB-231 Breast Cancer Cells. Cells were treated with CU $(10 \mathrm{mg} / \mathrm{ml})$ or DOX $(1 \mu \mathrm{M})$ alone or both for $48 \mathrm{hrs}$, then $(\mathrm{A})$ the morphological changes of MDA-MB-231 cells were recorded by cell observer microscope (20x) cell lysate was prepared, separated by SDS PAGE, and then assessed for (B) E-cadherin, N-cadherin, Vimentin, and $\beta$-Actin, (D) p-STAT3, STAT3, and ALDH1 (C) Cell localization of E-cadherin N-cadherin, and Vimentin were detected by Immunostaining. Significant differences $* p<0.05, * * p<0.01$, $* * * \mathrm{p}<0.001$ between control, DOX and combined treatment groups. 
A

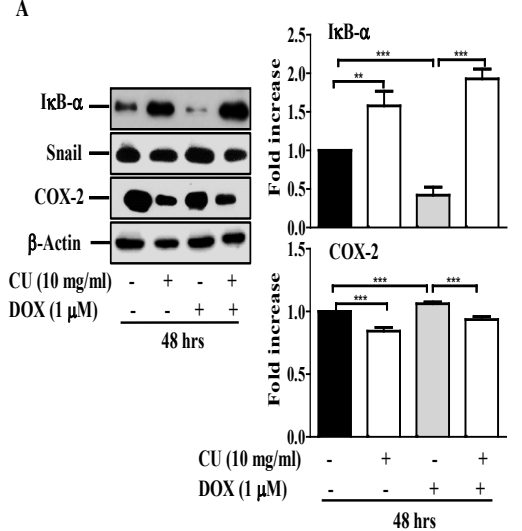

B

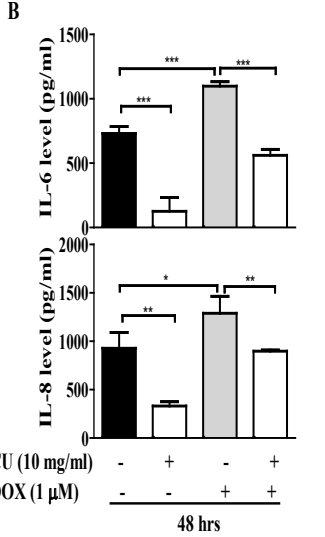

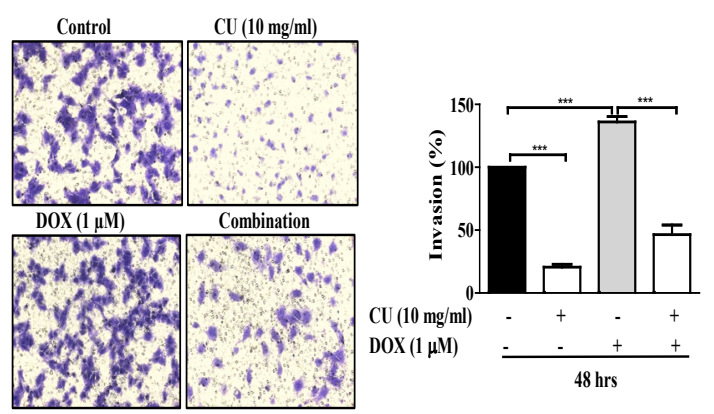

D

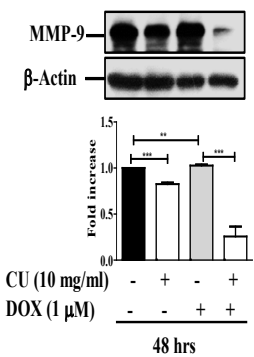

E
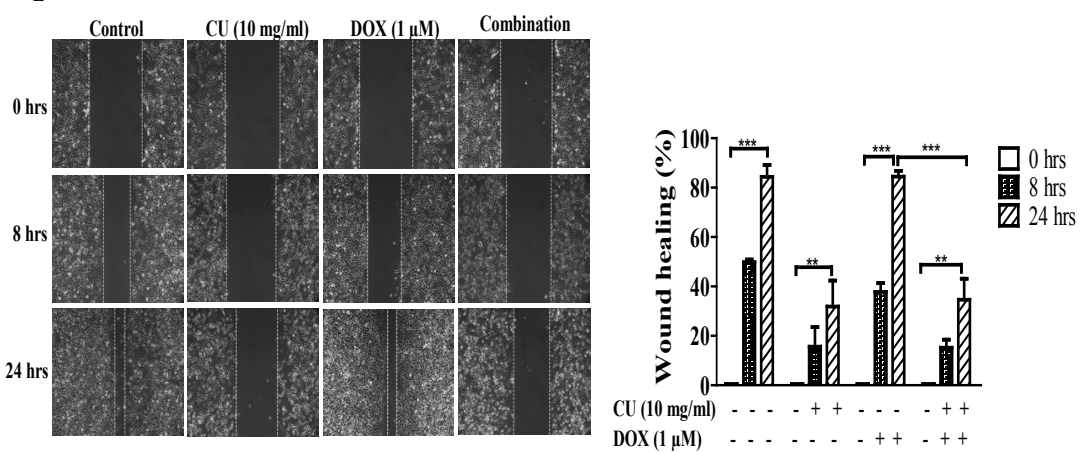

Figure 7. CU Reduces Inflammatory Mediators Production, Cell Migration and Invasion-Induced by Doxorubicin in MDA-MB-231 Breast Cancer Cells. Cells were treated with CU $(10 \mathrm{mg} / \mathrm{ml})$ or DOX $(1 \mathrm{mM})$ alone or both for $48 \mathrm{hrs}$, then cell lysates were prepared, separated by SDS PAGE, and assessed for (A) IkB-a, Snail, and COX-2. (D) MMP9 and b-Actin. (B) Media collected after incubation and cytokine levels for IL-6 and IL-8 were determined using ELISA assay kit. (C) Cell invasion assay was performed, and invaded cells were photographed (20x) and counted in 6 random fields for each treatment. (E) Cell migration was detected by scratch assay, Significant differences *p $<0.05$, $* * \mathrm{p}<0.01, * * * \mathrm{p}<0.001$ between control, DOX and combined treatment groups.

CU-treated cells was substantially impaired. Therefore, the CU treatment dramatically reduces both the motility and invasiveness of breast cancer cells.

\section{$C U$ enhances DOX cytotoxicity in MDA-MB-231 breast cancer cells}

We evaluated the possible synergistic cytotoxic effects of CU and DOX in co-treated cells. As shown in Figure $5 \mathrm{~A}$, the concurrent administration of DOX $(1 \mu \mathrm{M})$ and CU $(10 \mathrm{mg} / \mathrm{ml})$ significantly increased the sensitivity of cells to DOX-induced apoptosis. Cells morphology dramatically changed from a spindle-shaped morphology in the presence of DOX alone to a rounded and stressed morphology when DOX was co-administered with CU. Compared to the control, cell viability was significantly reduced from $82.8 \%$ in cells treated with DOX alone to $56.3 \%$ in cells co-treated with $\mathrm{CU}(\mathrm{P}<0.001)$. Consistent with these findings, an increase in the number of apoptotic MD-MB-231 cells was detected when CU was coadministered with DOX (Figure 5B). A significant \% of co-treated cells underwent apoptosis compared with DOXtreated cells $(\mathrm{P}<0.05)$. Moreover, the Western blot analysis showed that levels of $\mathrm{p}-\gamma-\mathrm{H} 2 \mathrm{AX}$ protein were significantly increased (Figure 5C) upon co-treatment with $\mathrm{CU}$ and DOX when compared to DOX alone $(\mathrm{P}<0.0001)$. Also, as expected in the presence of CU, DOX significantly reduced Bcl-xl protein expression compared to DOX treated cells alone $(\mathrm{P}<0.001)$ (Figure 5D). This result was consistent with the decrease in Bax protein expression in the cytosol and the increase in mitochondrial compartment compared to cells treated with DOX alone (Figure 5D). The increase in Bax: $\mathrm{Bcl}-\mathrm{xl}$ ratio suggested that the CU co-treatment enhanced DOX-induced activation of mitochondrial apoptosis pathway in MDA-MB-231 cells.

We further studied the effect of this combination on the induction of Caspase protein expression. As shown in Figure 5E, the combination remarkably attenuated proCaspase- 9 and subsequently pro-Caspase- 3 expression compared to cells treated with DOX alone $(\mathrm{P}<0.001$ and, $\mathrm{P}<0.01$, respectively). This decrease was associated with a significant increase in c-Caspase- 3 expression $(\mathrm{P}<0.001)$ and c-PARP $(\mathrm{P}<0.01)$ (Figure 5E). Thus, the effectiveness of DOX as a chemotherapeutic agent is enhanced in the presence of CU.

\section{$C U$ reverses DOX-induced EMT and CSC-associated} markers in MDA-MB-231 breast cancer cells

Since CU reverses EMT (Figure 3), we asked whether CU could also prevent chemotherapeutic drug induced EMT. We first investigated whether DOX could induce EMT in MDA-MB-231cells and as results in Figure $6 \mathrm{~A}$ shows, due to the spindle shaped morphology of 
MDA-MB-231 cells, the detection of additional EMT was difficult to visualize. Interestingly, Combining CU with DOX treatment remarkably transformed cells from spindle phenotype (mesenchymal phenotype) to a rounded or cobblestone phenotype (epithelial phenotype) (Figure 6A). We also observed a significant reduction in $\mathrm{N}$-cadherin $(\mathrm{P}<0.001)$ and Vimentin $(\mathrm{P}<0.001)$ protein expression when compared to cells treated with DOX alone (Figure 6B). On the other hand, E-cadherin protein expression was significantly increased when compared with DOX alone $(\mathrm{P}<0.05)$. This result was confirmed by immunofluorescence staining that showed a similar finding (Figure 6C). These data suggested that CU could reverse the DOX-induced EMT in breast cancer cells with Mesenchymal features.

The observation that EMT plays a role in the development of cancer stem cells suggests that therapies blocking or reversing EMT program may sensitize resistant cancer stem cells to conventional cancer therapies. For that, we evaluated the ability of CU to block EMT process and subsequent cancer stem cell formation by DOX treatment. The CU co-treatment successfully blocked DOX-mediated STAT activation when compared to cells treated with DOX alone $(\mathrm{P}<0.0001)$ (Figure 6D). As a result, STAT3-mediated stem cell marker ALDH1 protein expression was effectively suppressed $(\mathrm{P}<0.001)$ when compared to DOX alone (Figure 6D). Thus, the administration of CU during chemotherapy may sensitize carcinoma cells to the anti-tumour activities of chemotherapy.

$C U$ reduces the ability of DOX to induce inflammation, migration, and invasion in MDA-MB-231 breast cancer cells.

As shown in Figure 7A, while DOX stimulated NF- $\kappa \beta$ activation by inducing $\mathrm{I} \square \mathrm{B}-\square \square$ degradation $(\mathrm{P}<0.001)$, co-treatment with $\mathrm{CU}$ induced a significant reduction in $\mathrm{I} \square \mathrm{B}-\square \square$ degradation ( $\mathrm{P}<0.001)$ when compared to cells treated with DOX alone. As a result, we observed a decrease in the protein levels of the transcription factor Snail (Figure 7A) when compared to the increase detected in cells treated with DOX alone $(\mathrm{P}<0.001)$. Moreover, levels of COX-2 protein (Figure 7A) were significantly reduced in cells co-treated with $\mathrm{CU}(\mathrm{P}<0.01)$ when compared to DOX alone. Similarly, cytokine, IL-6 and IL-8, production was substantially affected (Figure 7B). Both were reduced in cells co-treated with $\mathrm{CU}(\mathrm{P}<0.001$ and $\mathrm{P}<0.01$, respectively).

We then examined whether $\mathrm{CU}$ is able to reverse DOX-induced motility and invasion of MDA-MB-231 cells (Figure 7C, D and E). As expected, DOX increased the invasion capacity of MDA-MB-231 cells (Figure 7C) compared to untreated control cells $(\mathrm{P}<0.001)$. This was significantly inhibited in the presence of CU $(\mathrm{P}<0.001)$. Cells also displayed a significant reduction in the levels of MMP-9 protein (Figure 7D) compared with cells treated with DOX alone $(\mathrm{P}<0.001)$. Similar trends were observed in wound healing assays (Figure 7E) as CU co-treatment remarkably suppressed DOX-induced cells migration. Overall, these findings indicate that $\mathrm{CU}$ treatment antagonizes the effect of DOX on inflammation, invasion and motility, thus enhancing its therapeutic outcomes.

\section{Discussion}

One of the aims of the present study was to explore possible pathways involved in CU inhibiting human breast cells proliferation and inducing apoptosis. Apoptosis is an active mechanism for the removal of unnecessary or defective cells and is necessary in multicellular organisms to sustain tissue homeostasis (Meier et al., 2000). It is associated with different cellular changes such as outer membrane permeabilization, chromatin condensation, mitochondrial swelling and DNA damage (Renault et al., 2015). The initiation of apoptosis is tightly regulated by two different pathways; mitochondrial intrinsic and death receptor extrinsic pathways (Golder et al., 2015). Mitochondria play important roles in apoptosis by controlling both pro-apoptotic and anti-apoptotic proteins. The results revealed CU to mediate an increase in the expression of mitochondrial Bax, a pro-apoptotic protein, along with a decrease of Bcl-xl, anti-apoptotic protein, thereby altering the cytosolic Bax: Bcl-2 ratio. Also, a significant decrease in Caspases-9, Caspase-3 and upregulation of c-Caspase- 3 and its proteolytic substrate PARP upon CU treatment corroborated well with the activation of the intrinsic mitochondrial apoptotic pathway. Moreover, $\gamma-\mathrm{H} 2 \mathrm{AX}$, a marker of DNA damage, was increased in a concentration-dependent manner which resulted as a consequence of DNA fragmentation caused by activated Caspases to eliminate cells by apoptosis (Ljungman, 2010). This was confirmed by flow cytometry analysis of apoptotic cells. Nevertheless, the pathways by which CU induces DNA damage is yet unclear and warrants further investigation.

EMT has been indicated as a crucial cancer progression mechanism by which epithelial cells develop mesenchymal, fibroblast-like phenotypes with a decrease in cell-to-cell adhesion, cell polarity loss, and consequently enhanced migration and invasiveness (Singh and Settleman, 2010). This phenomenon is believed to facilitate the tumor cells migration from their site of origin to distant tissues upon activation of a particular genetic program (Kalluri and Weinberg, 2009a, Mulholland et al., 2012). Also, it has been documented that EMT protein markers play an essential role in cancer as E-cadherin expression loss and $\mathrm{N}$-cadherin expression gain in cancer cells have functional importance in cancer progression and metastasis (Araki et al., 2011).Thus, blocking or reversing EMT process may provide a successful therapeutic approach to limit the diffusion of cancer. Our study showed that in mesenchymal cells, CU not only restored an epithelial phenotype, but also reversed EMT. The MET program include enhancement of E-cadherin and occluding expression, reduction in $\mathrm{N}$-cadherin, Vimentin, and nuclear $\beta$-catenin expression, which results in acquisition of an epithelial phenotype (Schmalhofer et al., 2009). Interestingly, CU markedly increased the protein expression of E-cadherin and significantly reduced $\mathrm{N}$-cadherin and Vimentin proteins, which was also confirmed by immunostaining. This resulted in a downregulation of the high levels of MMP-9 secreted in breast cancer cell line MDA-MB-231. 
MMP-9 belongs to MMPs family of endopeptidases that have a proteolytic activity responsible for degrading the basement membrane during the EMT process and consider as an important regulator of invasion and metastasis in breast cancer (Eiseler et al., 2009). As consequence, the migration and invasiveness of breast cancer cells were significantly inhibited by CU-induced MET. Furthermore, cells that undergo the EMT have been shown to acquire stem cell-like properties, and the EMT and cancer stem cell (CSC) development are interrelated processes (Mani et al., 2008). Also, evidence has revealed that EMT could induce CSC features (Mani et al., 2008). Interestingly, CU successively decreased the expression of ALDH1 protein, a marker of CSCs, suggesting that CSC development may be affected in a way by the CU treatment. To the best of our knowledge, our research is the first to prove that in cultured breast cancer cells, the anti-metastatic effects of $\mathrm{CU}$ are correlated with the EMT process.

Inflammation is well known for affecting different tumor development stages, starting from the initiation phase to the metastatic phase (Karin, 2006). One of the multiple pathways used by cancer cells to initiate inflammation and to promote tumor growth and progression is NF- $\kappa \mathrm{B}$ pathway (Grivennikov et al., 2010). It is believed that EMT is induced and maintained by cytokines and other inflammatory mediators (Scheel et al., 2011). Also, NF- $\kappa \mathrm{B}$ showed to play a crucial role in EMT via Snail transcription activation (Chua et al., 2007). The current data revealed that MDA-MB-231 breast cancer cells constitutively phosphorylate NF$\kappa \mathrm{B}$ and inhibit I $\mathrm{KB}-\alpha$ protein. This observation is in agreement with previous finding (Monks and Pardee, 2006). CU suppressed successfully NF- $\kappa$ B activation and subsequently its downstream transcription factor, Snail. This result is consistent with a previous study that showed CU significantly inhibited NF- $\kappa$ B mRNA along with its downstream inflammatory mediators in mice tumours (Romli et al., 2017). Also, it was shown that the persistence of tumour cells post-EMT depend on cytokine and/or growth factor supply that was initially responsible for EMT induction in the same cells (Scheel et al., 2011). The present data revealed a high expression of IL-6 and IL- 8 in MDA-MB-231 breast cells, both are downstream cellular target of NF- $\kappa \beta$ (Al-Halabi et al., 2011), which was remarkably decreased by CU. Moreover, a significant reduction in STAT3 phosphorylation was detected. It is documented that IL-6 to activate JAK/ STAT3 signaling pathway which is frequently found in various human cancers including breast cancer (Huang et al., 2010, Liu et al., 2014) and plays a significant role in EMT (Huang, 2007, Colomiere et al., 2009). Furthermore, cyclooxygenase-2 (COX-2), another inflammatory mediator, that is known to be upregulated by NF- $\kappa \mathrm{B}$ (StGermain et al., 2004, Jang et al., 2000) and promote the migration and invasion of malignant cancer cells (Chen et al., 2013, Kim et al., 2014) was significantly reduced by CU. This in light with previous study that showed inhibition of NF- $\kappa$ B in MDA-MB-231 breast cancer cells leads to $\mathrm{COX}-2$ protein expression reduction (Xu et al., 2015). These findings support and offer a mechanistic rationale for $\mathrm{CU}$ inhibition of tumor progression and might indicate that $\mathrm{CU}$ may prevent the metastasis of breast cancer by suppressing both EMT and CSC due to its anti-inflammatory effects.

EMT has been associated with chemoresistance to several chemotherapeutic agents (Zhang et al., 2012, Virag et al., 2013, Morikawa et al., 2015, Sadreddini et al., 2017). Intriguingly, the establishment of EMT lineage-tracing method in mice revealed that following chemotherapeutic, mice cells undergoing EMT were found in the primary tumor and exhibited chemoresistance with high genes linked to chemoresistance expression (Fischer et al., 2015). This may indicate the importance of EMT in cancer drug resistance and post-chemotherapy metastasis. We tried in the current study to explore whether $\mathrm{CU}$ in combination with chemotherapeutic drugs such as DOX, can synergistically reverse drug resistance in breast cancer cells. The results revealed that $\mathrm{CU}$ antagonizes DOX-induced EMT through the downregulation of $\mathrm{N}$-cadherin and Vimentin (mesenchymal cell markers) and upregulation of E-cadherin (epithelial marker). This strongly enhanced cells invasion and migration inhibition when compared to cells treated with DOX alone. This effect was achieved in a part by downregulating MMP-9 protein expression. Moreover, the combination treatment significantly induced mitochondria-dependent apoptosis in MDA-MB-231 cells, as both Caspase- 9 and -3 proteins levels were significantly decreased and both levels of c-Caspase-3 and c-PARP protein levels increased. These finding were supported by the reduction in cells viability, the massive induction of apoptotic cells detected by flow cytometry, and the high activation of $\square \square \mathrm{H} 2 \mathrm{AX}$. Thus, the result suggest that CU induces cells sensitivity to DOX-induced cells death. Also, CU successfully reversed EMT-induced stemness as determined by the loss of ALDH1 protein expression which is considered as a potent marker of stemness and commonly used to identify cells displaying resistance to conventional cancer treatments (Marcato et al., 2011). Furthermore, the present study showed that combination therapy inhibits the stimulatory effect of DOX on NF- $\kappa$ B-Snail signaling and its downstream targets, STAT-3. COX-2, IL-6 and IL-8, all of which are involved in EMT.

In conclusion, although CU exact mode of action requires further investigation, our results provide a new mechanistic bases for its therapeutic application in breast cancer therapy, not just as a single agent, but in combination with other anti-cancer drugs, DOX. CU showed a remarkable ability in inducing apoptosis in MDA-MB-231 cells which was solely through the intrinsic mitochondria-mediated pathway. Also, the present study demonstrates for the first time the ability of CU to inhibit tumor invasion, metastasis and chemoresistance, which is associated with perturbations in EMT, either alone or in combination with DOX. CU inhibited the activation of NF- $\kappa \mathrm{B}-$ Snail signaling and regulated the expression of important downstream EMT protein markers, E-cadherin, $\mathrm{N}$-cadherin and Vimentin and subsequently stemness. Our findings provide a new perspective on the role of $\mathrm{CU}$ in preventing cancer progression and expand our understanding of the mechanism by which $\mathrm{CU}$ may act to inhibit the invasiveness and metastasis and the 
chemoresistance of cancer cells.

\section{Author Contribution Statement}

Al-Mutairi, MS., idea generation designed all experiments, analyzed the data and drafted the manuscript. Matar, IK., conceived the experiments. AlFadhli, SA., helped in editing the paper. Al-Mutairi, AS., helped in analyzing the data.

\section{Acknowledgments}

The author would like to acknowledge Mr. Muhammad Faraj Alsubaie for generously and continuously providing camel urine. Dr Khaled Orabi, Faculty of Pharmacy, Kuwait university for camel urine samples preparation. Dr Abdelilah Aboussekhra, King Faisal Specialist Hospital and Research Center, KSA for support and guidance.

\section{Funding statement}

This work was funded in part by Kuwait University (Grant NM01/10) and Health Science Center RCF (grant SRUL02/13). The funder had no role in the study design, data collection and analysis, decision to publish, and manuscript preparation.

\section{Availability of data}

All the data are included within the article.

\section{Conflict of interest}

The authors declare that there is no conflict of interest.

\section{References}

Abdullah, IN, Chow, EK (2013). Mechanisms of chemoresistance in cancer stem cells. Clin Transl Med, 2, 3.

Ahamad, SR, Alhaider, AQ, Raish, M, Shakeel, F (2017). Metabolomic and elemental analysis of camel and bovine urine by GC-MS and ICP-MS. Saudi J Biol Sci, 24, 23-9.

AL-bashan MM (2011). In vitro assessment of the antimicrobial activity and biochemicalpropertiesof camel's urine against some human pathogenic microbes. Middle East J Sci Res, 7, 947-58.

AL-halabi R, Bouchedid M, Aboumerhi R, et al (2011). Gallotannin inhibits NFKB signaling and growth of human colon cancer xenografts. Cancer Biol Ther, 12, 59-68.

AL-yousef N, Gaafar A, AL-otaibi, B, et al (2012). Camel urine components display anti-cancer properties in vitro. $J$ Ethnopharmacol, 143, 819-25.

AL-ghamdi Z (2012). Cytotoxicity of the urine of different camel breeds on theproliferation of lung cancer cells, A549. J Nat Sci Res, 2, 9-16.

Araki, K, Shimura, T, Suzuki, H, et al (2011). E/N-cadherin switch mediates cancer progression via TGF- $\beta$-induced epithelial-to-mesenchymal transition in extrahepatic cholangiocarcinoma. Br J Cancer, 105, 1885-93.

Bai, L, Yang, HH, Hu, Y, Shukla, A, Ha, NH, et al (2016). An integrated genome-wide systems genetics screen for breast cancer metastasis susceptibility genes. PLoS Genet, 12, 1-18.

Brabletz T (2012). EMT and MET in metastasis: where are the cancer stem cells?. Cancer Cell, 22, 699-701.

Chaffer CL, Weinberg RA (2011). A perspective on cancer cell metastasis. Science, 331, 1559-64.

Chen CC, Hsieh TF, Chang CH, et al (2013). Androgen receptor promotes the migration and invasion of upper urinary tract urothelial carcinoma cells through the upregulation of MMP-9 and COX-2. Oncol Rep, 30, 979-85.

Chua HL, Bhat-nakshatri P, Clare SE, Morimiya, A, Badve S (2007). NF-kappaB represses E-cadherin expression and enhances epithelial to mesenchymal transition of mammary epithelial cells: potential involvement of ZEB-1 and ZEB-2. Oncogene, 26, 711-24.

Cichon, MA, Radisky, DC (2014). ROS-induced epithelialmesenchymal transition in mammary epithelial cells is mediated by NF-kB-dependent activation of Snail. Oncotarget, 5, 2827-38.

Colomiere M, Ward AC, Riley C, et al (2009). Cross talk of signals between EGFR and IL-6R through JAK2/STAT3 mediate epithelial-mesenchymal transition in ovarian carcinomas. Br J Cancer, 100, 134-44.

Delivani P, Martin SJ (2006). Mitochondrial membrane remodeling in apoptosis: an inside story. Cell Death Differentiation, 13, 2007-10.

Eiseler T, Döppler H, Yan IK, Goodison S, Storz P (2009). Protein kinase D1 regulates matrix metalloproteinase expression and inhibits breast cancer cell invasion. Breast Cancer Res, 11, R13.

Elinav E, Nowarski R, Thaiss CA, et al (2013). Inflammationinduced cancer: crosstalk between tumours, immune cells and microorganisms. Nat Rev Cancer, 13, 759-71.

Fischer KR, Durrans A, Lee S, et al (2015). Epithelial-tomesenchymal transition is not required for lung metastasis but contributes to chemoresistance. Nature, 527, 472-6.

Goldar S, Khaniani MS, Derakhshan SM, Baradaran B (2015). Asian Pac J Cancer Prev, 16, 2129- 44.

Grivennikov SI, Greten FR, Karin M (2010). Immunity, inflammation, and cancer. Cell, 140, 883-99.

Groblewska M, Mroczko B, Szmitkowski M (2010). The role of selected matrix metalloproteinases and their inhibitors in colorectal cancer development. Postepy Hig Med Dosw, 64, 22-30.

Gupta SC, Sundaram C, Reuter S, Aggarwal BB (2010). Inhibiting NF- $\kappa \mathrm{B}$ activation by small molecules as a therapeutic strategy. Biochim Biophys Acta, 1799, 775-87.

Hou P, Zhao Y, Li Z, Yao R, Ma M (2014). LincRNA-ROR induces epithelial-to-mesenchymal transition and contributes to breast cancer tumorigenesis and metastasis. Cell Death Dis, 5, 1-10.

Hu SH, Wang CH, Huang ZJ, et al (2016). miR-760 mediates chemoresistance through inhibition of epithelial mesenchymal transition in breast cancer cells. Eur Rev Med Pharmacol Sci, 20, 5002-8.

Huang C, Yang G, Jiang T, et al (2010). Effects of IL-6 and AG490 on regulation of Stat3 signaling pathway and invasion of human pancreatic cancer cells in vitro. $J$ Exp Clin Cancer Res, 29, 51.

Huang, S (2007). Regulation of metastases by signal transducer and activator of transcription 3 signaling pathway: clinical implications. Clin Cancer Res, 13, 1362-6.

Jang, BC, Sanchez T, Schaefers HJ, Trifan OC, Liu CH (2000). Serum withdrawal-induced post-transcriptional stabilization of cyclooxygenase-2 mRNA in MDA-MB-231 mammary carcinoma cells requires the activity of the p38 stressactivated protein kinase. J Biol Chem, 275, 39507-15.

Jing Y, Han Z, Zhang S, Liu Y, Wei L (2011). EpithelialMesenchymal Transition in tumor microenvironment. Cell Biosci, 1, 29.

Kalluri R, Weinberg RA (2009a). The basics of epithelialmesenchymal transition. J Clin Invest, 119, 1420-28.

Kalluri R, Weinberg RA (2009b). The basics of epithelialmesenchymal transition. J Clin Invest, 119, 1420-8. 
Karin M (2006). Nuclear factor-kappaB in cancer development and progression. Nature, 441, 431-6.

Kim MJ, Kim HS, Lee SH, Yang Y, Lee MS (2014). NDRG2 controls COX-2/PGE-mediated breast cancer cell migration and invasion. Mol Cells, 37, 759-65.

Kubiliute R, Sulskyte I, Daniunate K, Daugelavicius R, Jarmalaitie S (2016). Molecular features of doxorubicinresistance development in colorectal cancer CX-1 cell line. Medicina (Kaunas), 52, 298-306.

Liu, RY, Zeng, Y, Lei, Z, Wang, L, Yang, H (2014). JAK/ STAT3 signaling is required for TGF- $\beta$-induced epithelialmesenchymal transition in lung cancer cells. Int J Oncol, 44, 1643-51.

Ljungman M (2010). The DNA damage response--repair or despair?. Environ Mol Mutagen, 51, 879-89.

ManiSA, Guo W,Liao MJ, etal(2008). The epithelial-mesenchymal transition generates cells with properties of stem cells. Cell, 133, 704-15.

Mantovani A (2018). The inflammation - cancer connection. FEBS J, 285, 638-40 .

Marcato P, Dean CA, Giacomantonio CA, Lee PW (2011). Aldehyde dehydrogenase: its role as a cancer stem cell marker comes down to the specific isoform. Cell Cycle, 10, 1378-84.

Marotta LL, Almendro V, Marusyk A, et al (2011). The JAK2/ STAT3 signaling pathway is required for growth of CD44-CD24- stem cell-like breast cancer cells in human tumors. J Clin Invest, 121, 2723-35.

Meier P, Finch A, Evan G (2000). Apoptosis in development. Nature, 407, 796-801.

Min C, Eddy SF, Sherr DH, Sonenshein GE (2008). NF-kB and epithelial to mesenchymal transition of cancer. $J$ Cell Biochem, 104, 733-44.

Monks NR, Pardee AB (2006). Targeting the NF-kappa B pathway in estrogen receptor negative MDA-MB-231 breast cancer cells using small inhibitory RNAs. $J$ Cell Biochem, 98, 221-33.

Morikawa Y, Kezuka C, Endo S, et al (2015). Acquisition of doxorubicin resistance facilitates migrating and invasive potentials of gastric cancer MKN45 cells through up-regulating aldo-keto reductase 1B10. Chem Biol Interact, 230, 30-9.

Mulholland DJ, Kobayashi N, Ruscetti M, et al (2012). Pten loss and RAS/MAPK activation cooperate to promote EMT and metastasis initiated from prostate cancer stem/progenitor cells. Cancer Res, 72, 1878-89.

Polyak K, Weinberg RA (2009). Transitions between epithelial and mesenchymal states: acquisition of malignant and stem cell traits. Nat Rev Cancer, 9, 265-73.

Renault TT, Floros KV, Elkholi R (2015). Mitochondrial shape governs BAX-induced membrane permeabilization and apoptosis. Mol Cell, 57, 69-82.

Romli F, Abu N, Khorshid FA, et al (2017). The growth inhibitory potential and antimetastatic effect of camel urine on breast cancer cells in vitro and in vivo. Integr Cancer Ther, 16, 540-55.

Sadreddini S, Safarlizadeh R, Baradaran B, et al (2017). Chitosan nanoparticles as a dual drug/siRNA delivery system for treatment of colorectal cancer. Immunol Lett, 181, 79-86.

Scheel C, Eaton EN, Li SH, et al (2011). Paracrine and autocrine signals induce and maintain mesenchymal and stem cell states in the breast. Cell, 145, 926-40.

Schmalhofer O, Brablet, S, Brabletz T (2009). E-cadherin, beta-catenin, and ZEB1 in malignant progression of cancer. Cancer Metastasis Rev, 28, 151-66.

Siegel RL, Miller KD, Jemal A (2020). Cancer statistics. CA Cancer J Clin, 70, 7-30.
Singh A, Settleman J (2010). EMT, cancer stem cells and drug resistance: an emerging axis of evil in the war on cancer. Oncogene, 29, 4741-51.

Sobolewski C, Cerella C, Dicato M, Ghibelli L, Diederich M (2010). The role of cyclooxygenase-2 in cell proliferation and cell death in human malignancies. Int J Cell Biol, 2010, 215158.

Song R, Song H, Liang Y, et al (2014). Reciprocal activation between ATPase inhibitory factor 1 and NF- $\kappa$ B drives hepatocellular carcinoma angiogenesis and metastasis. Hepatology, 60, 1659-73.

ST-germain M, Gagnon V, Parent S, Asselin E (2004). Regulation of COX-2 protein expression by Akt in endometrial cancer cells is mediated through $\mathrm{NF}-\mathrm{\kappa B} / \mathrm{I} \kappa \mathrm{B}$ pathway. Mol Cancer, 3,7 .

Sung H, Ferlay J, Siegel R, et al (2021). Global cancer statistics 2020: GLOBOCAN Estimates of Incidence and Mortality Worldwide for 36 Cancers in 185 Countries. CA Cancer J Clin, 71, 209-49.

Thiery JP, Acloque H, Huang RY, Nieto MA (2009). Epithelialmesenchymal transitions in development and disease. Cell, 139, 871-90.

Turner, NC, Reis-filho, JS (2013). Tackling the diversity of triple-negative breast cancer. Clin Cancer Res, 19, 6380-8.

Velasco-velázquez MA, Popov VM, Lisanti MP, Pestell RG (2011). The role of breast cancer stem cells in metastasis and therapeutic implications. Am J Pathol, 179, 2-11.

Virag P, Fischer-fodor E, Perde-schrepler M, Brie I, Tatomir CV (2013). Oxaliplatin induces different cellular and molecular chemoresistance patterns in colorectal cancer cell lines of identical origins. BMC Genomics, 14, 480.

$\mathrm{Xu}$ HD, Cho SC, Bang MA, Bae CS, Choi Y (2015). FK-3000 isolated from Stephania delavayi Diels. inhibits MDA-MB-231 cell proliferation by decreasing NF- $\mathrm{BB}$ phosphorylation and COX-2 expression. Int J Oncol, 46, 2309-16.

Yan C, Grimm WA, Garner WL, Qin L, Travis T (2010). Epithelial to mesenchymal transition in human skin wound healing is induced by tumor necrosis factor-alpha through bone morphogenic protein-2. Am J Pathol, 176, 2247-58.

Yao J, Duan L, Fan M, Yuan J, WU X (2007). Notch1 induces cell cycle arrest and apoptosis in human cervical cancer cells: involvement of nuclear factor kappa B inhibition. Int J Gynecol Cancer, 17, 502-10.

Zhang W, Feng M, Zheng G, Chen Y, Wang X (2012). Chemoresistance to 5-fluorouracil induces epithelialmesenchymal transition via up-regulation of Snail in MCF7 human breast cancer cells. Biochem Biophys Res Commun, 417, 679-85.

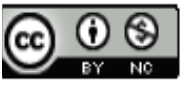

This work is licensed under a Creative Commons AttributionNon Commercial 4.0 International License. 